\title{
Quinalizarin enhances radiosensitivity of nasopharyngeal carcinoma cells partially by suppressing SHP-1 expression
}

\author{
XIAOFEN PAN ${ }^{*}$, RUI MENG ${ }^{2 *}$, ZHONGHUA YU $^{1}$, JINGJING MOU $^{2}$, SHA LIU $^{2}$, \\ ZIYI SUN ${ }^{2}$, ZHENWEI ZOU ${ }^{2}$, GANG WU ${ }^{2}$ and GANG PENG ${ }^{2}$ \\ ${ }^{1}$ Oncology Center, Affiliated Hospital of Guangdong Medical College, Zhanjiang, Guangdong 524000; ${ }^{2}$ Cancer Center, \\ Union Hospital, Tongji Medical College, Huazhong University of Science and Technology, Wuhan, Hubei 430030, P.R. China
}

Received October 16, 2015; Accepted November 22, 2015

DOI: $10.3892 /$ ijo.2016.3338

\begin{abstract}
The purpose of this study was to investigate the influence of quinalizarin on the radiosensitivity of nasopharyngeal carcinoma (NPC) cells and the relevant underlying mechanisms. Human NPC cell lines CNE-1, CNE-2 and $5-8 \mathrm{~F}$ were treated with quinalizarin and then irradiated with different X-rays doses. Cell viability, survival, DNA double-strand breaks (DSB), apoptosis, cell cycle distribution, expression of SHP-1 and other related proteins were detected with MTT assay, colony formation assay, immunofluorescent assay, flow cytometry and western blot analysis, respectively. We also examined how the effects of quinalizarin were affected by SHP-1-overexpression by lentivirus transfection. Quinalizarin at $25 \mu \mathrm{M}$ enhanced radiosensitivity of NPC cells. This increased radiosensitivity was due to inhibition of cell viability, which delayed DSB repair as seen by significantly increased $\gamma$-H2AX foci, promoting apoptosis by $34 \%$ in CNE-1 and $9 \%$ in CNE-2 cells compared to controls and changing cell cycle distribution in CNE-1, but not CNE-2 cells. Quinalizarin treatment obviously decreased SHP-1 protein expression. Overexpressing SHP-1 partially reversed the radiosensitive effect of quinalizarin. Quinalizarin inhibited binding of p65 and the promoter of SHP-1, and decreased the activities of SHP-1 promoter and SHP-1. Quinalizarin enhanced radiosensitivity of NPC cells partially by suppressing SHP-1 expression.
\end{abstract}

\section{Introduction}

Ionizing radiation (IR) is the primary therapy for nasopharyngeal carcinoma (NPC). Though most NPC cells are sensitive

Correspondence to: Dr Gang Peng, Cancer Center, Union Hospital, Tongji Medical College, Huazhong University of Science and Technology, Wuhan, Hubei 430030, P.R. China

E-mail: penggangcancer@126.com

${ }^{*}$ Contributed equally

Key words: quinalizarin, SHP-1, nasopharyngeal carcinoma, CK2, $\mathrm{p} 65$, radiosensitivity to IR, there are still some tumor cells which are resistant to irradiation. These radioresistant cancer cells often result in local recurrence and metastasis after radiotherapy (1). Thus, finding drugs that can enhance NPC therapy is of great significance.

In recent years, new drugs that target tyrosine kinase have made a breakthrough in tumor therapy (2). Because targeted therapy is highly specific and causes fewer side effects than chemotherapy, targeted therapy has become increasingly widely accepted by patients and doctors $(3,4)$. To date a number of different kinds of tyrosine kinase inhibitors (TKIs) have been approved by the Food and Drug Administration (FDA), such as Imatinib (Gleevec), Gefitinib (Iressa), Erlotinib (Tarceva), and Sorafenib (Nexavar). In addition, there are still many other TKIs undergoing different stages of preclinical and clinical trials (5).

CK2 is an important Ser/Thr kinase that is expressed in most eukaryotes. The CK2 complex is a tetramer composed of two catalytic subunits ( $\alpha \alpha$ or $\alpha \alpha^{\prime}$ ) and two regulatory subunits $(\beta \beta)$ (6). Using ATP and GTP as phosphate group donors, CK2 phosphorylates the ser/thr residues of its substrates. Substrates of CK2 such as nuclear factor- $\kappa \mathrm{B}$ $(\mathrm{NF}-\kappa \mathrm{B}), \mathrm{Dsh} / \mathrm{Dvl}$, the product of the adenomatous polyposis coli gene, transcription elements Lef/Tcf, engrailed, and $\beta$-catenin are involved in signal transduction, DNA replication, transcription, translation and many other important events (7). Therefore, CK2 plays a vital role in cell growth, proliferation, differentiation, apoptosis and is considered to be a potential target for regulation of some cell processes such as cell cycle distribution, apoptosis and DNA damage repair (8-10). Some studies have found that CK2 inhibitors can inhibit cancer cell growth and promote apoptosis (10-12). Further research indicated that CK2 took part in DNA damage repair by affecting the binding of DNA-PKcs and DNA (13). Lin et al found that inhibiting CK2 activity increased radiosensitivity of nonsmall cell lung cancer (NSCLC) cells through decreasing stat 3 activation (14). These studies suggest that CK2 may be a potential target to enhance radiosensitivity of tumor cells, including NPC cells.

Traditional CK2 inhibitors include TBB, TBI/TBBz, and DMAT. However, the selectivity of these inhibitors was not found to be as narrow as it was originally believed (15). Therefore, new CK2 inhibitors have been investigated. 
Quinalizarin is an ATP-site competitive CK2 inhibitor. It is highly selective and cell-permeable and the selectivity of quinalizarin toward CK2 is superior to any other CK2 inhibitor known so far $(16,17)$. Thus, we used quinalizarin as a CK2 selective inhibitor in this study and assessed its influence on NPC radiosensitivity.

SHP-1, also named PTPN6, PTP1C, HCP, HCPH, HPTP1C, SH-PTP1 (18), is an SH2 domain-containing protein tyrosine phosphatase (PTP) consisting of 17 exons and 16 introns that spans $\sim 17 \mathrm{~kb}$ of DNA $(19,20)$. SHP-1 shows high expression in normal hematopoietic cells and low expression in many hematological malignancies (21), including Burkitt lymphomas (22), natural killer cell lymphoma (23), diffuse large cell lymphoma, follicular lymphoma, Hodgkin's disease, mantle cell lymphoma, peripheral T-cell lymphoma, adult T-cell lymphoma and leukemia, plasmacytoma (24), and chronic myeloid leukemia (25). Thus, SHP-1 is traditionally regarded as a tumor suppressor. However, some studies have found that SHP-1 is highly expressed in some epithelial carcinoma cells, such as certain types of ovarian cell lines and breast cell lines (26). Despite considerable research into SHP-1 in hematological tumors, the functions of SHP-1 in solid tumors, especially in NPC, are poorly understood. Our previous investigation found that SHP-1 was highly expressed in NPC tissues in contrast to normal nasopharyngeal mucosa and was associated with local recurrence and metastasis after radiotherapy in NPC patients (27). Knocking down SHP-1 by siRNA in the NPC cell line CNE-2 and the non-small cell lung carcinoma (NSCLC) cell line A549 enhanced radiosensitivity, which was an outcome of cell cycle redistribution $(28,29)$.

In this study, we used quinalizarin as a CK2 specific inhibitor and explored its impact on NPC cell radiosensitivity and we also investigated its influence on NPC cell proliferation, apoptosis, cell cycle distribution and DNA damage repair. In addition, we explored how quinalizarin affects the expression of SHP-1.

\section{Materials and methods}

Cell culture and irradiation procedure. Human nasopharyngeal carcinoma cell lines CNE-1 and CNE-2 were obtained from the Cell Bank of Sun Yat-sen University (Guangzhou, China). The nasopharyngeal carcinoma cell line $5-8 \mathrm{~F}$ was obtained from the Cell Bank of The Second Xiangya Hospital of Central South University (Hunan, China). Cells were routinely cultured in RPMI-1640 (Hyclone, USA) medium supplemented with $12 \%$ fetal bovine serum (Hyclone), and $1 \%$ penicillin/streptomycin (Hylcone). The cells were maintained at $37^{\circ} \mathrm{C}$ in a humidified incubator with $5 \% \mathrm{CO}_{2}$ and $95 \%$ air.

Irradiation was performed at room temperature with a single dose of X-rays ranging from 2 to 8 Gy using a linear accelerator (Primus K, Siemens, Munich, Bayern, Germany) with $6 \mathrm{MV}$ photons $/ 100 \mathrm{~cm}$ focus-surface distance with a dose rate of $2.0 \mathrm{~Gy} / \mathrm{min}$.

Establishment of radioresistant nasopharyngeal carcinoma cell sublines. Radioresistant NPC cells were established according to a previously published method (27). Exponentially growing CNE-1 and CNE-2 cells were irradiated with a dose of 6 Gy x 5. There was a 7-9-day break between the the doses.
The surviving sublines (CNE-1R and CNE-2R clones) were then passaged for three months and their radiosensitivity was determined (Table I).

MTT assay. Cells (3,000-4,000 cells/well) were seeded into 96-well culture dishes, the next day they were treated with quinalizarin (Merck, Germany) dissolved in DMSO at $50 \mathrm{mM}$ then diluted in RPMI-1640 medium at 0 (0.05\% DMSO), 25, 50 and $100 \mu \mathrm{M}$. The plates were then incubated for 24, 48 and $72 \mathrm{~h}$, respectively. MTT (20 $\mu$ l) (Sigma, St. Louis, MO, USA) $(5 \mathrm{mg} / \mathrm{ml})$ was added to the wells and incubated in the dark for $4 \mathrm{~h}$. The culture media was removed, and $150 \mu \mathrm{l}$ DMSO added then the plates were slowly shaken for $15 \mathrm{~min}$. The OD value at $490 \mathrm{~nm}$ test wavelength and $630 \mathrm{~nm}$ reference wavelength was measured with a microplate reader system (Bio-Tek, USA). Cell viability rate $=\mathrm{OD}_{\text {experimental group }} / \mathrm{OD}_{\text {control group }}$.

Colony formation assay. Cells were seeded into 6-well culture dishes, at cell densities of 200,300,600, 1,500, and 4,000 cells/well, for the $0,2,4,6$ and 8 Gy experiments, respectively, but with the same cell density between $25 \mu \mathrm{M}$ quinalizarin and $0.05 \%$ DMSO groups. The cells were treated with $25 \mu \mathrm{M}$ quinalizarin or $0.05 \%$ DMSO the next day for $24 \mathrm{~h}$ and then irradiated at the different doses $(0,2,4,6$, and $8 \mathrm{~Gy})$ the radiotherapy time was based on the dose at $2 \mathrm{~Gy} / \mathrm{min}$. Plates were incubated for $\sim 14$ days, fixed with methanol, stained with Giemsa, and colonies containing $\geq 50$ cells were counted as a clone. The multi-target click model was used to describe the survival fraction. $\mathrm{SF}=1-\left(1-\mathrm{e}^{-\mathrm{D} / \mathrm{D} 0}\right)^{\mathrm{N}}(\mathrm{SF}$, cell survival fraction; $\mathrm{D}$, radiation dose; e, the bottom of the natural logarithm; $\mathrm{D}_{0}$, the mean death dose; $\mathrm{N}$, extrapolate number) was used to fit cell survival curves. The sensitization enhancing ratio (SER) was calculated as a ratio of $\mathrm{D}_{0}$. $\mathrm{N}$ reflects the ability of cells to repair damage caused by radiation, if $\mathrm{N}$ increases, the dose required to kill the cells increases. Dq represents the quasi-threshold amount required for cell damage, as Dq increases the cell survival curve has a widened shoulder area and enhanced radiation resistance.

Immunofluorescent assay (IFA). Cells (5,000 cells/well) were treated with $25 \mu \mathrm{M}$ quinalizarin or $0.05 \%$ DMSO for $24 \mathrm{~h}$ then irradiated with a dose of $2 \mathrm{~Gy}$ for $0.5,3,6$ and $24 \mathrm{~h}$. At specific times after IR, cells were harvested, and fixed in $4 \%$ paraformaldehyde for $15 \mathrm{~min}$. After being washed with PBS three times, the cells were permeabilized with Triton X-100 for 15 min on ice. After being washed with PBS again three times, the cells were blocked with 5\% BSA for $30 \mathrm{~min}$ at room temperature (RT), and then immunostained with anti- $\gamma$-H2AX (Abcam, Cambridge, UK) at $4^{\circ} \mathrm{C}$ overnight. After further washes with PBS three times, the cells were incubated with Dylight 488 labeled secondary antibody (EarthOx Life Sciences, Millbrae, CA, USA) for $1 \mathrm{~h}$, then washed with PBS three times, the nucleus was stained with Hoechst 33258 (Wuhan Google Biological Technology Co., Ltd., China) for 15 min at RT. Photographs were captured by Olympus Laser scanning confocal microscopy (Olympus Optical Co., Tokyo, Honshu, Japan). For each treatment condition, $\gamma$-H2AX foci number per cell were counted in $\geq 50$ cells under confocal microscopy with high magnification (x800) by two independent reviewers who were blinded to the grouping. 
Table I. Parameters of radiosensitivity in the three cell lines treated with different concentrations of quinalizarin.

\begin{tabular}{|c|c|c|c|}
\hline $\begin{array}{l}\text { Quinalizarin } \\
\text { concentration }\end{array}$ & CNE-1 & CNE-2 & $5-8 \mathrm{~F}$ \\
\hline \multicolumn{4}{|l|}{$0 \mu \mathrm{M}$} \\
\hline $\mathrm{N}$ & 1.33 & 1.63 & 1.66 \\
\hline $\mathrm{SF} 2$ & 0.47 & 0.53 & 0.58 \\
\hline D0 & 2.08 & 2.02 & 2.25 \\
\hline $\mathrm{Dq}$ & 1.02 & 1.19 & 1.32 \\
\hline \multicolumn{4}{|l|}{$12.5 \mu \mathrm{M}$} \\
\hline $\mathrm{N}$ & 1.24 & 2.07 & 1.65 \\
\hline SF2 & 0.44 & 0.56 & 0.55 \\
\hline D0 & 2.01 & 1.79 & 2.09 \\
\hline $\mathrm{Dq}$ & 0.92 & 1.31 & 1.24 \\
\hline \multicolumn{4}{|l|}{$25 \mu \mathrm{M}$} \\
\hline $\mathrm{N}$ & 1.41 & 1.19 & 1.23 \\
\hline $\mathrm{SF} 2$ & 0.34 & 0.31 & 0.33 \\
\hline D0 & 1.48 & 1.53 & 1.55 \\
\hline $\mathrm{Dq}$ & 0.74 & 0.60 & 0.64 \\
\hline \multicolumn{4}{|l|}{$50 \mu \mathrm{M}$} \\
\hline $\mathrm{N} 2.12$ & 1.65 & 1.14 & \\
\hline SF2 & 0.22 & 0.17 & 0.17 \\
\hline D0 & 0.91 & 0.88 & 1.06 \\
\hline $\mathrm{Dq}$ & 0.66 & 0.38 & 0.18 \\
\hline \multicolumn{4}{|l|}{$100 \mu \mathrm{M}$} \\
\hline $\mathrm{N}$ & 0.46 & 1.09 & 0.88 \\
\hline SF2 & 0.09 & 0.09 & 0.04 \\
\hline D0 & 1.19 & 0.79 & 0.67 \\
\hline $\mathrm{Dq}$ & -0.59 & -0.15 & -0.53 \\
\hline
\end{tabular}

Flow cytometric analysis of the cell cycle. Cells treated with $25 \mu \mathrm{M}$ quinalizarin or $0.05 \%$ DMSO for $24 \mathrm{~h}$ were then irradiated with $6 \mathrm{~Gy}$ X-rays. The cells were harvested $24 \mathrm{~h}$ after IR, fixed overnight with $70 \%$ ethanol, then resuspended in PBS containing $1 \mathrm{mg} / \mathrm{ml}$ RNase A (Sigma) and $50 \mu \mathrm{g}$ / $\mathrm{ml}$ propidium iodide (Sigma). The cellular DNA content was determined on a flow cytometer FACScan (BectonDickinson, San Jose, CA, USA). Quantifications of cells in the G0/G1, S, G2/M phases were performed using CellQuest software (BD).

TUNEL analysis of apoptosis. Cells $\left(5 \times 10^{5}\right.$ cells/well) were seeded into 6-well plates, treated with $0.05 \%$ DMSO or $25 \mu \mathrm{M}$ quinalizarin for $24 \mathrm{~h}$ and then irradiated with X-rays (6 Gy), and $24 \mathrm{~h}$ after IR, cells were fixed with $4 \%$ paraformaldehyde, treated with Triton X-100. The assay was performed according to the manufacturer's instructions of the TUNEL kit (Roche Applied Science, Shanghai, China). Apoptosis were observed by fluorescence microscopy (Olympus IX71, Olympus Optical Co., Tokyo, Japan). Cells with green fluorescence were regarded as apoptotic cells.
Overexpression of SHP-1. CNE-2 cells were planted at 24-well plates, and incubated with $0.5 \mathrm{ml}$ RPMI-1640 supplemented with $15 \%$ heat-inactivated fetal bovine serum, $1 \%$ penicillin/streptomycin (Hyclone). After 24-h incubation, $50 \mu \mathrm{l} /$ well lentivirus-mediated SHP-1 overexpression (8.6x10 ${ }^{9}$ copies/ml) (GeneCopoeia Inc. Guangzhou, China) was added into the CNE- 2 cells for $48 \mathrm{~h}$. The stably transfected cells were selected using medium containing $2 \mu \mathrm{g} / \mathrm{ml}$ puromycin (supplemented with 10\% heat-inactivated fetal bovine serum, penicillin/streptomycin) for 12 days. Positive clones were obtained and screened by RT-PCR for transfection efficiency. The medium containing puromycin was changed once every three days.

Quantitative real-time RT-PCR. Total RNA was extracted by TRIzol (Invitrogen, Carlsbad, NM, USA) and reverse transcription was used to obtain cDNA, according to the Takara RT-PCR kit manufacturer's instructions (Takara, Japan). Primer sequences were as follows: SHP-1: forward, 5'-ACCAT CATCCACCTCAAGTACC-3'; reverse, 5'-CTGAGCACAGA AAGCACGAA-3'; $\beta$-actin: forward, 5'-GATGAGATTGGCA TGGCTTT-3'; reverse, 5'-CACCTTCACCGTTCCAGTTT-3'. Then qPCR was performed according to the SYBR Green manufacturer's instructions (ABI, USA) in a PCR thermocycler (ABI PRISM 7000, USA) using $95^{\circ} \mathrm{C}$ for $30 \mathrm{sec}$, then $95^{\circ} \mathrm{C}$ for $5 \mathrm{sec}, 60^{\circ} \mathrm{C}$ for $35 \mathrm{sec}, 95^{\circ} \mathrm{C}$ for $15 \mathrm{sec}, 60^{\circ} \mathrm{C}$ for $1 \mathrm{~min}$, and $95^{\circ} \mathrm{C} 15 \mathrm{sec}$, for 35 cycles. StepOne ${ }^{\mathrm{TM}}$ software v2.1 was used to analyze the data. The $C_{t}$ value was defined as the number of PCR cycles in which the fluorescence signal exceeded the detection threshold value. First, $\Delta \mathrm{Ct}=\mathrm{Ct}$ Gene $-\mathrm{Ct} \beta$-actin . Then, $\Delta \Delta \mathrm{Ct}=\Delta \mathrm{Ct}$ treated $-\Delta \mathrm{Ct}$ control. Lastly, $2^{-\Delta \Delta \mathrm{Ct}}$ was calculated to represent the relative mRNA expression of target genes. $\beta$-actin was used as an internal control.

Western blot analysis. Cells were harvested and lysed in RIPA buffer (Wuhan Google Biological Technology Co., Ltd.). Protein concentrations of the lysates were determined by the BCA protein assay system (Google, Wuhan, China). Equal amounts of protein $(40-80 \mu \mathrm{g})$ were separated by $8-12 \%$ SDS-PAGE, and transferred to PVDF membrane (Millipore, Billerica, MA, USA). The membranes were blocked with 5\% BSA, and then probed with either anti-SHP-1 (Epitomics, Burlingame, CA, USA), anti-NF-кB p65 (Cell Signaling Technology, USA), anti-phospho-NF-кB p65 (Cell Signaling Technology), or anti-GAPDH (Santa Cruz, Dallas, TX, USA) primary antibodies. After washing, the membrane was incubated with the appropriate horseradish peroxidase secondary antibody (Invitrogen) and visualized by chemiluminescence using a chemiluminescence kit (Invitrogen) and the specific bands were recorded on X-ray film. GAPDH protein levels were used as a control to verify equal protein loading.

EMSA. EMSA was performed using the gel-shift assay system using the EMSA kit (Thermo Fisher Scientific, Waltham, MA, USA). Probe sequences of SHP-1 promoter used in EMSA were as follows: forward, 5'-GGCCACGCCTGGGCGCT TCC-3'; reverse, 5'-GGAAGCGCCCAGGCGTGGCC-3'. To prepare DNA probes, double-stranded DNA probes were incubated at $95^{\circ} \mathrm{C}$ for $5 \mathrm{~min}$, and slowly cooled down to room temperature. Concentration of probe was $0.5 \mu \mathrm{M}$. The 
following reagents were added to the tubes and incubated at $37^{\circ} \mathrm{C}$ for 30 min: ultrapure water $25 \mu 1,5 \mathrm{X}$ TdT reaction buffer $10 \mu \mathrm{l}$, unlabeled oligo $(1 \mu \mathrm{M}) 5 \mu \mathrm{l}$, biotin-11-UTP $(5 \mu \mathrm{M}) 5 \mu \mathrm{l}$, diluted TdT $(2 \mathrm{U} / \mu \mathrm{l}) \mathrm{Ul}$. Then $2.5 \mu \mathrm{l}$ EDTA $(0.2 \mathrm{M})$ was added to stop the reaction. The labeled DNA probe was collected. The nuclear extracts were prepared according to the manual of the EMSA kit. Then, the nuclear extracts were incubated with the p65 antibodies (Cell Signaling Technology) for $10 \mathrm{~min}$ at room temperature. The protein/DNA complexes were resolved on 4-6\% polyacrylamide gels and transferred to the membrane (Millipore, Billerica, MA, USA). Subsequently, the complex was visualized by chemiluminescence using a chemiluminescence kit (Invitrogen).

Dual luciferase assay. p-GL3 basic was from Transgene (Bejing, China). Linear vector was constructed using KpnI (10 U/ $/ 1)$ and XholI (10 U/ $/ \mu \mathrm{l})$ DNase. The SHP-1 promoter sequence was connected to the linear vectors. DNA plasmids were transiently transfected into NPC cells with $10 \mu \mathrm{l}$ Lipo2000 (Invitrogen). Cells were harvested $60 \mathrm{~h}$ after transfection and lysed in $100 \mu \mathrm{l} 1 \mathrm{X}$ cell culture by 513 reagent. Upon adjusting protein concentration, $20 \mu \mathrm{l}$ of each lysate was assayed in replicates for luciferase activity according to the manufacturer's instructions (Promega, Madison, WI, USA).

SHP-1 activity assay. Cells were treated with DMSO or quinalizarin for 0,12 and $24 \mathrm{~h}$ then total protein were extracted by RIPA lysis buffer containing $1 \%$ PMSF. Total protein was incubated with anti-SHP-1 primary antibody overnight at $4^{\circ} \mathrm{C}$. Protein A-Sepharose (Merck) were added to each sample and then incubated for $3 \mathrm{~h}$ at $4^{\circ} \mathrm{C}$ with rotation. After immuoprecipitation reaction, the protein-antibody complex was separated from the protein A-sepharose by centrifugation $\left(4^{\circ} \mathrm{C}\right.$, 3,000 rpm, $3 \mathrm{~min}$ ). Then the complex was resuspended with PBS. SHP-1 activity was determined by RediPlate 96 EnzChek Tyrosine Phosphatase Assay kit (R-22067, Molecular Probes, Invitrogen) according to the manufacturer's instructions.

Statistical analysis. SPSS 17.0 for Windows (SPSS Inc., Chicago, IL, USA) was used for statistical analysis. Experimental data were expressed as mean \pm standard deviation (SD) from at least three independent experiments. Differences in measured variables between experimental and control groups were assessed using t-test and ANOVA with least significant difference (LSD). The criterion for statistical significance was $\mathrm{P}<0.05$.

\section{Results}

Quinalizarin $(25 \mu \mathrm{M})$ enhances radiosensitivity but has little effect on NPC cell proliferation. To investigate the effect of quinalizarin on radiosensitivity of NPC cells, we performed colony formation assays. Fig. 1A indicates that irradiation killed the tumor cells exponentially in CNE-1, CNE-2 and $5-8 \mathrm{~F}$. All three NPC of the cell lines showed a lower survival fraction after being treated with quinalizarin at different IR doses. These effects were quinalizarin dose related. $\mathrm{D}_{0}, \mathrm{D}_{\mathrm{q}}$, $\mathrm{N}, \mathrm{SF}_{2}$ were also generally lower in the quinalizarin groups than that in the dimethyl sulfoxide (DMSO) groups, which represents higher sensitivity to IR. Although at some doses
$\mathrm{N}$ was increased suggesting that the capacity of the cells for repair was increased. At $100 \mu \mathrm{M}$ quinalizarin, $\mathrm{D}_{\mathrm{q}}$ was negative, possibly because the drug alone was enough to kill the cells, and the role of radiotherapy was secondary. At $25 \mu \mathrm{M}$ overall the enhancement ratio of quinalizarin groups were 1.41, 1.18 and 1.52 for CNE-1, CNE-2 and 5-8F, respectively.

We used different concentrations of quinalizarin to treat NPC cells for 24, 48 and $72 \mathrm{~h}$, respectively. MTT assays were performed to test cell viability. As shown in Fig. 1B, quinalizarin inhibited cell viability in a concentration- and time-dependent manner. At $25 \mu \mathrm{M}$, the inhibitory rates of all the three cell lines were $<20 \%$, at $24 \mathrm{~h}(0.839 \pm 0.0587$ for CNE-1, $0.924 \pm 0.0527$ for CNE-2 and $0.894 \pm 0.0209$ for $5-8 \mathrm{~F}$ compared to the normalized value of 1 for controls). At 48 and 72 h, cell viability decreased sharply. When concentration was increased to $50 \mu \mathrm{M}$, the inhibitory efficiency of CNE-2 and 5-8F were $~ 20 \%$ while in CNE-1 was $50 \%$. Consequently, we used $25 \mu \mathrm{M}$ quinalizarin treatment for $24 \mathrm{~h}$ in the later experiments as this value enhanced radiosensitivity, but had little effect on cell proliferation.

Quinalizarin slows down DSB repair. DNA double-strands break (DSB) is one of the most important of DNA damage caused by irradiation and the ability to repair DSB is one of the important influencing factors for radiosensitivity. $\gamma-\mathrm{H} 2 \mathrm{AX}$ foci are vital markers of DSB (1). To detect how quinalizarin influence DSB repair in NPC cells, we used immunofluorescent assays (IFA) to examine the formation of $\gamma-\mathrm{H} 2 \mathrm{AX}$ foci in the DMSO and quinalizarin groups before and at different times after IR. Before IR, quinalizarin treated cells had more $\gamma$-H2AX foci than DMSO treated cells. Not surprisingly, 0.5, 3,6 and $24 \mathrm{~h}$ after IR, quinalizarin treated cells still had more $\gamma$-H2AX foci than DMSO treated cells. The three cell lines CNE-1, CNE-2 and 5-8F all showed similar results and they were significantly different from the DMSO groups at all timepoints $(\mathrm{P}<0.001$, Fig. 2$)$. The results suggested that quinalizarin slowed down the efficiency of DSB repair in NPC cells.

Quializarin increases the fraction of NPC cells in $G 2 / M$ phase and apoptosis. One of the mechanisms that influences radiosensitivity is cell cycle distribution. It is well-known that cells are most sensitive to irradiation in $\mathrm{G} 2 / \mathrm{M}$ phase. Thus, we used flow cytometry to detect the cell cycle distribution in the two groups before or after IR. In CNE-1, the cell fractions in G2/M phase were not significantly different between DMSO and quinalizarin group before IR $(11.38 \pm 1.21$ vs. $12.40 \pm 1.76 \%$, respectively). After IR, however, cell proportion in $\mathrm{G} 2 / \mathrm{M}$ phase was significantly higher in quinalizarin group $(23.02 \pm 0.16$ vs. $30.55 \pm 2.22 \%, \mathrm{P}=0.04)$, We also found that the change of cell cycle distribution in CNE-2 was the same as with CNE-1. Cell fractions in G2/M phase were not significantly different between DMSO and quinalizarin group before IR $(12.28 \pm 2.22$ vs. $12.46 \pm 0.65 \%$, respectively). After IR, however, cells proportion in $\mathrm{G} 2 / \mathrm{M}$ phase was significantly higher in quinalizarin group $(16.50 \pm 0.70$ vs. $25.06 \pm 2.41 \%$, $\mathrm{P}=0.004$ ) (Fig. 3A).

To examine the effect of quinalizarin on apoptosis before and after IR, we used TUNEL assays to determine the apoptotic rate of NPC cells. Without irradiation by X-ray, the apoptosis rates of the DMSO group was almost equal to the quinalizarin group in both cell lines with rates of 6.6 and $6.7 \%$, respectively, 
A
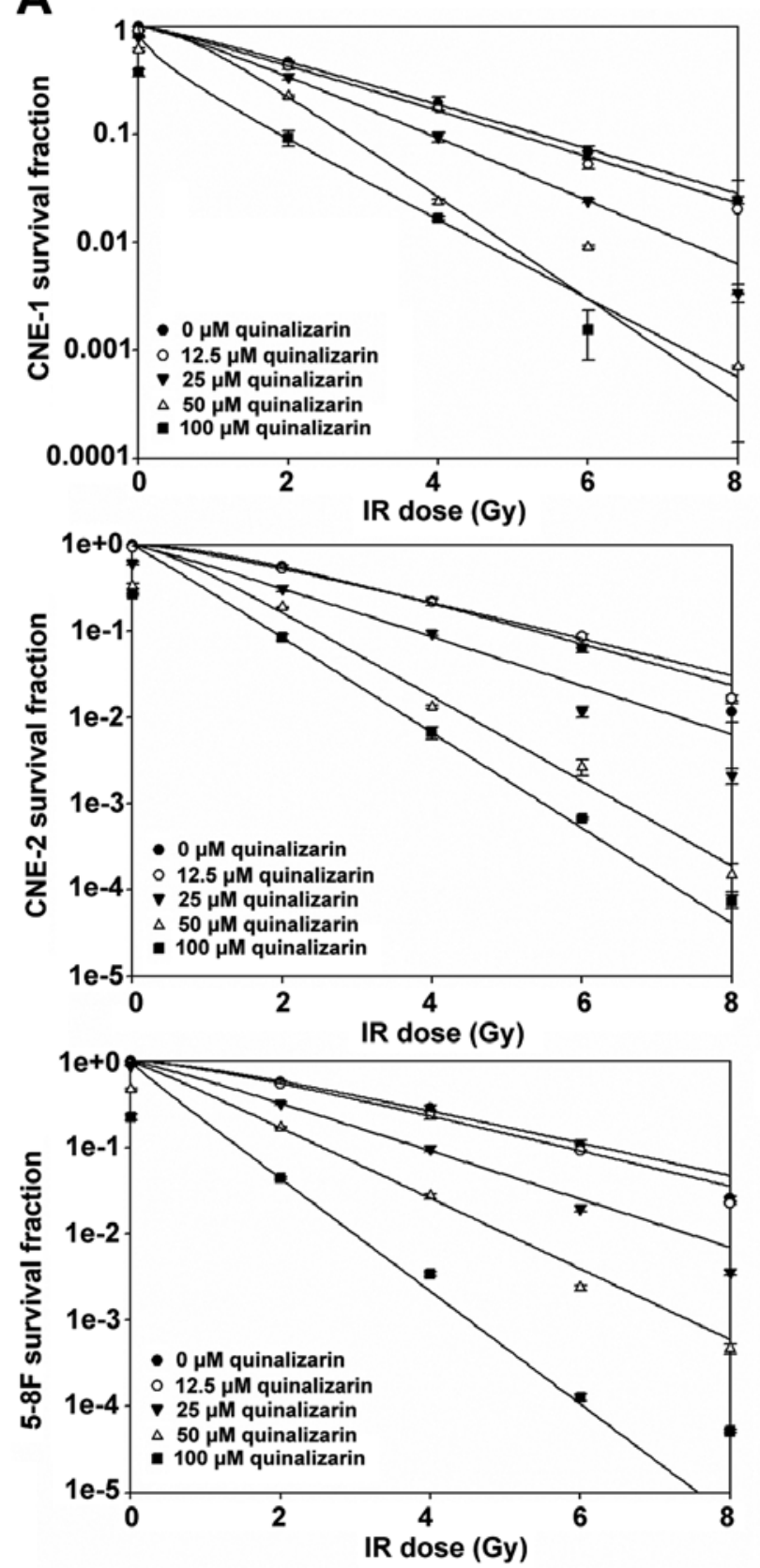

B
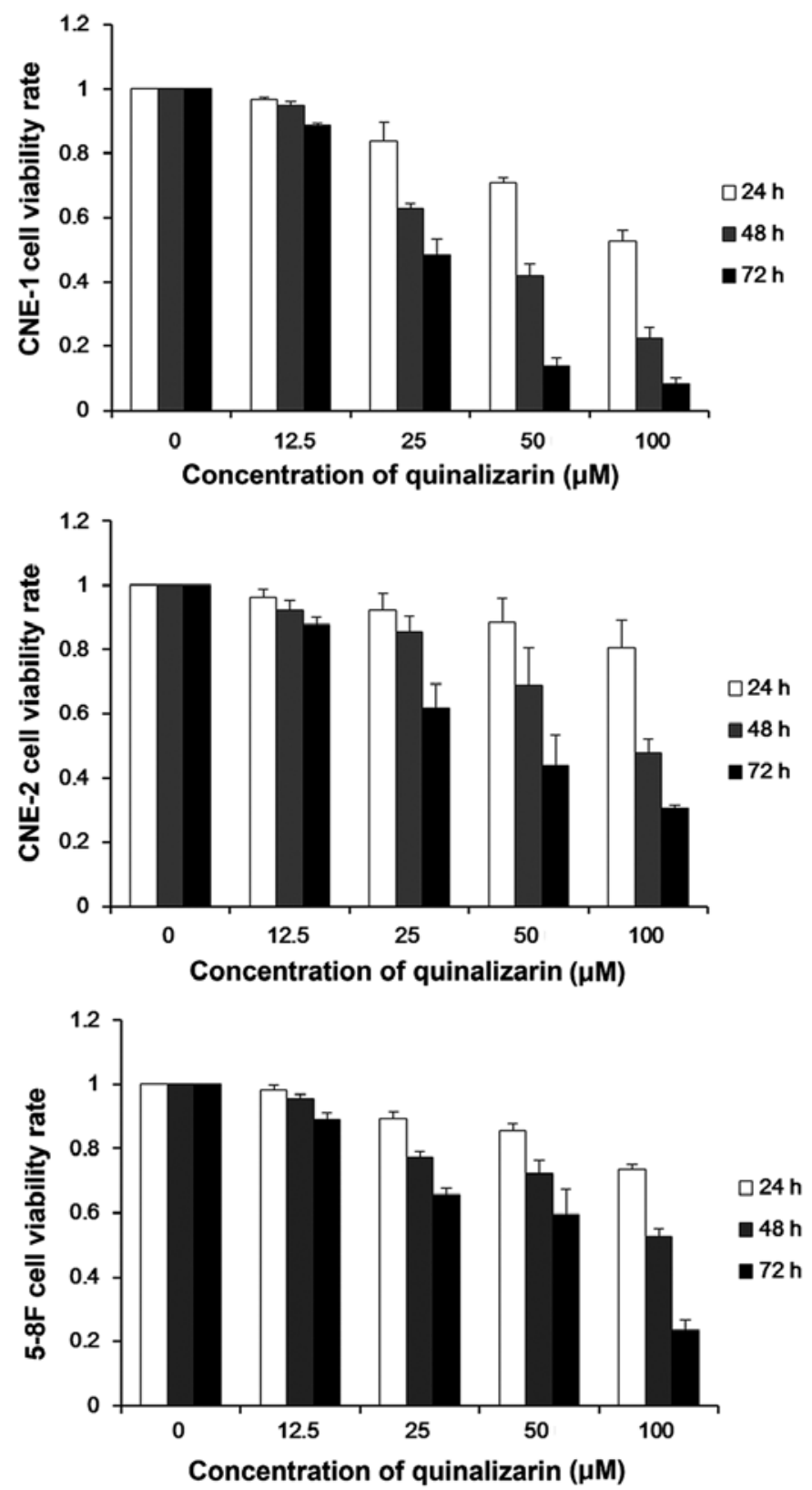

Figure 1. Effects of quinalizarin on nasopharyngeal carcinoma (NPC) cell radiosensitivity and viability. (A) CNE-1, CNE-2 and 5-8F cells were treated with $0,12.5,25,50$ and $100 \mu \mathrm{M}$ quinalizarin for $24 \mathrm{~h}$ and then irradiated at the different doses (0, 2, 4, 6 and $8 \mathrm{~Gy}$ ) (radiation absorption rate is $2 \mathrm{~Gy} / \mathrm{min})$. After further incubation for $\sim 14$ days, clone formation assays were used to examine radiosensitivity of the NPC cells. Survival curves were fitted according to the multi-target single-hit model. IR, ionizing radiation; (B) CNE-1, CNE-2 and 5-8F cells were treated with $0,12.5,25,50$ and $100 \mu \mathrm{M}$ quinalizarin for 24,48 and $72 \mathrm{~h}$, respectively. MTT assays were performed to examine cell viability rates relative to the control group ( $0 \mu \mathrm{M}$ quinalizarin, $0.05 \%$ DMSO) (control group was normalized to 1$)$. The data are shown as mean \pm standard deviation (SD).

in CNE-1, 7.6 and 8.3\%, respectively, in CNE-2. After irradiation by X-ray, apoptosis rates between the two groups showed significant differences. The apoptosis rates of the quinalizarin group were 34\% higher than the DMSO group in CNE-1 and 9\% higher in CNE-2 (Fig. 3B). Based on these results, we concluded that quinalizarin promoted apoptosis in NPC cells after IR.

Quinalizarin suppresses SHP-1 expression in radioresistant NPC cells. Radioresistant populations of CNE-1 and CNE-2 cells (Fig. 4A and B) were treated with quinalizarin and this successfully increased their radiosensitivity (Fig. 4C and D). The levels of SHP-1 were then evaluated in the cells by western blot analyses, while the levels in the radioresitant populations were higher than the parent cells (Fig. 4E), the levels in the radioresistant cells that were then treated with quinalizarin were obviously decreased (Fig. 4F).

Overexpression of SHP-1 abolished the radiosensitive effect of quinalizarin. Therefore, we thought that the enhanced radiosensitivity acquired from quinalizarin may depend on its 


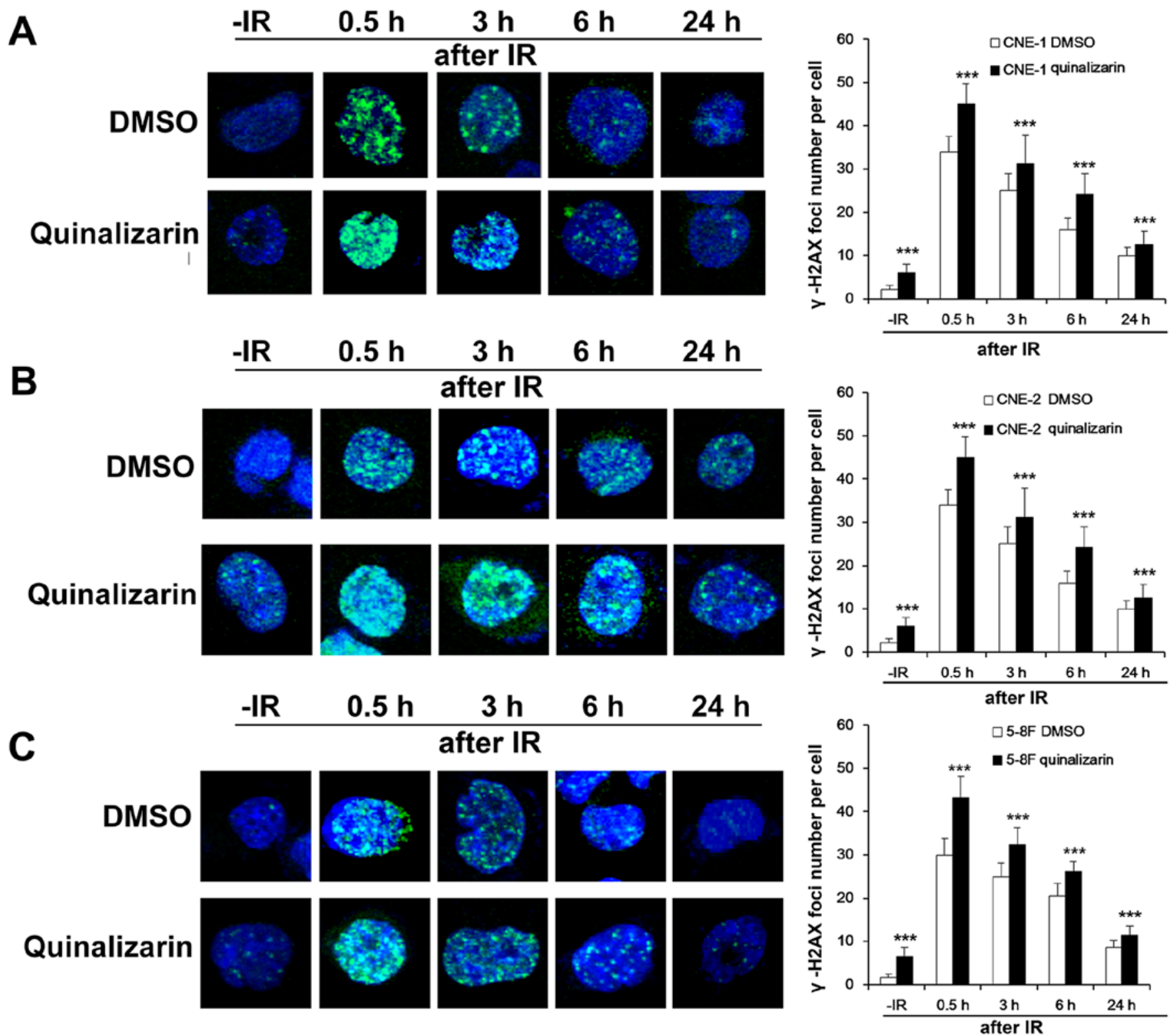

Figure 2. Effects of quinalizarin on DNA double-strand breaks (DSB) induced by ionizing radiation (IR) in NPC cells. (A) CNE-1; (B) CNE-2; (C) 5-8F cells were treated with $25 \mu \mathrm{M}$ quinalizarin for $24 \mathrm{~h}$, and then irradiated at $2 \mathrm{~Gy}$. -IR represents NPC cells treated with $0.05 \%$ DMSO or $25 \mu \mathrm{M}$ quinalizarin alone for $24 \mathrm{~h} .0 .5,3,6$ or $24 \mathrm{~h}$ after IR, $\gamma$-H2AX foci are vital markers of DSB, and were immunofluorescently stained with an anti- $\gamma$-H2AX antibody to detect DSB repair under laser scanning confocal microscope (LSCM) (magnification, x400). Green, Dylight 488; blue, Hoechst 33258. $\gamma$-H2AX foci number per cell were counted in $\geq 50$ cells. The data are shown as means \pm SD from three independent experiments. ${ }^{* * *} \mathrm{P}<0.001$ vs. $0.05 \%$ DMSO group.

downregulation of SHP-1. To verify our hypothesis, we used lentivirus to transfect CNE-2 and produced a cell line with high levels of SHP-1 expression (referred to as LP-H802Lv201) and a negative control which only contained the vector (referred to as LP-NegLv201) (Fig. 5A and B). We then performed colony formation assays to test the effect of quinalizarin on radiosensitivity of LP-Neglv201 and LP-H1802Lv201. Survival curves showed that quinalizarin treated LP-NegLv201 had a smaller shoulder area than DMSO treated LP-NegLv201, representing higher radiosensitivity. In LP-H1802Lv201, however, being treated with quinalizarin did not display significant enhancement of radiosensitivity, compared with quinalizarin treated LP-NegLv201 (Fig. 5C). Results showed that overexpressing SHP-1 reversed the radiosensitive effect of quinalizarin. Thus, we can conclude, as least partially, that quinalizarin radiosensitized NPC cells by suppressing the expression of SHP-1.

Quinalizarin inhibits binding of 065 and the promoter of SHP-1 and decreases the activity of SHP-1 promoter. Western blot analysis showed that quinalizarin decreased SHP-1 expression, but not p65, a subunit of NF- $\kappa \mathrm{B}$; however, the level of phosphorylated p65 was decreased with quinlizarin (Fig. 6A). To verify whether quinalizarin affected the binding of p65 and SHP-1 promoter, the SHP-1 promoter probe was used for EMSA. The CNE-1 and CNE-2 nuclear proteins were extracted and an anti-p65 Ab was used to precipitate $\mathrm{p} 65$. Then the complex of p65 Ab and p65 was used for EMSA to detect its binding to SHP-1 promoter. We noted that treatment with quinalizarin obviously reduced the binding 
A
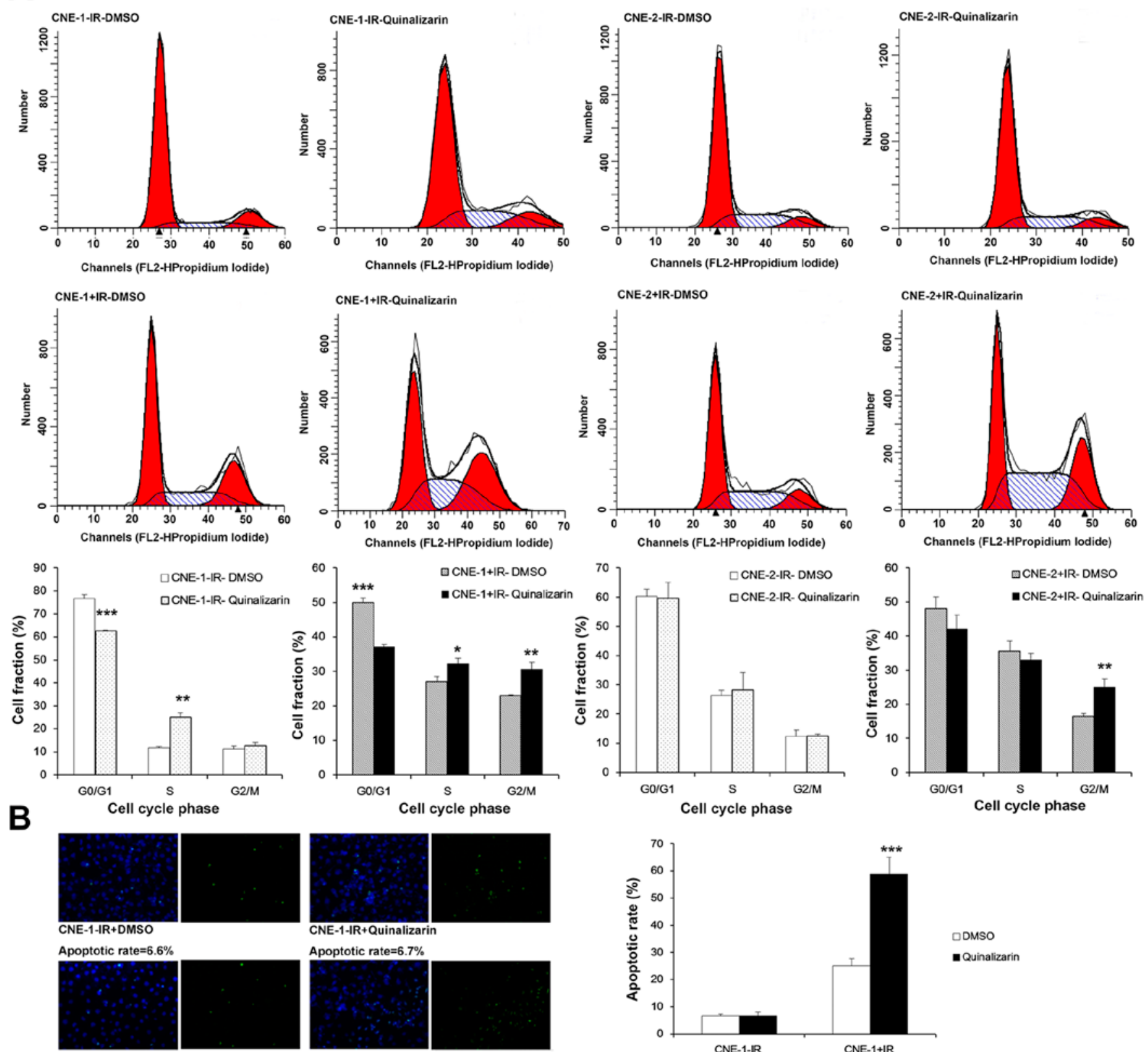

Apoptotic rate $=6.7 \%$
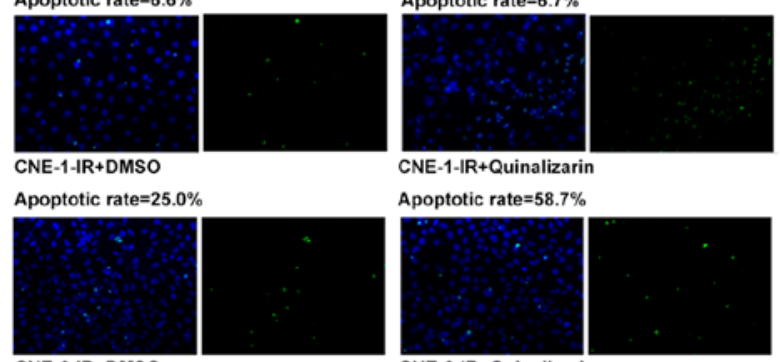

CNE-1-IR+Quinalizarin
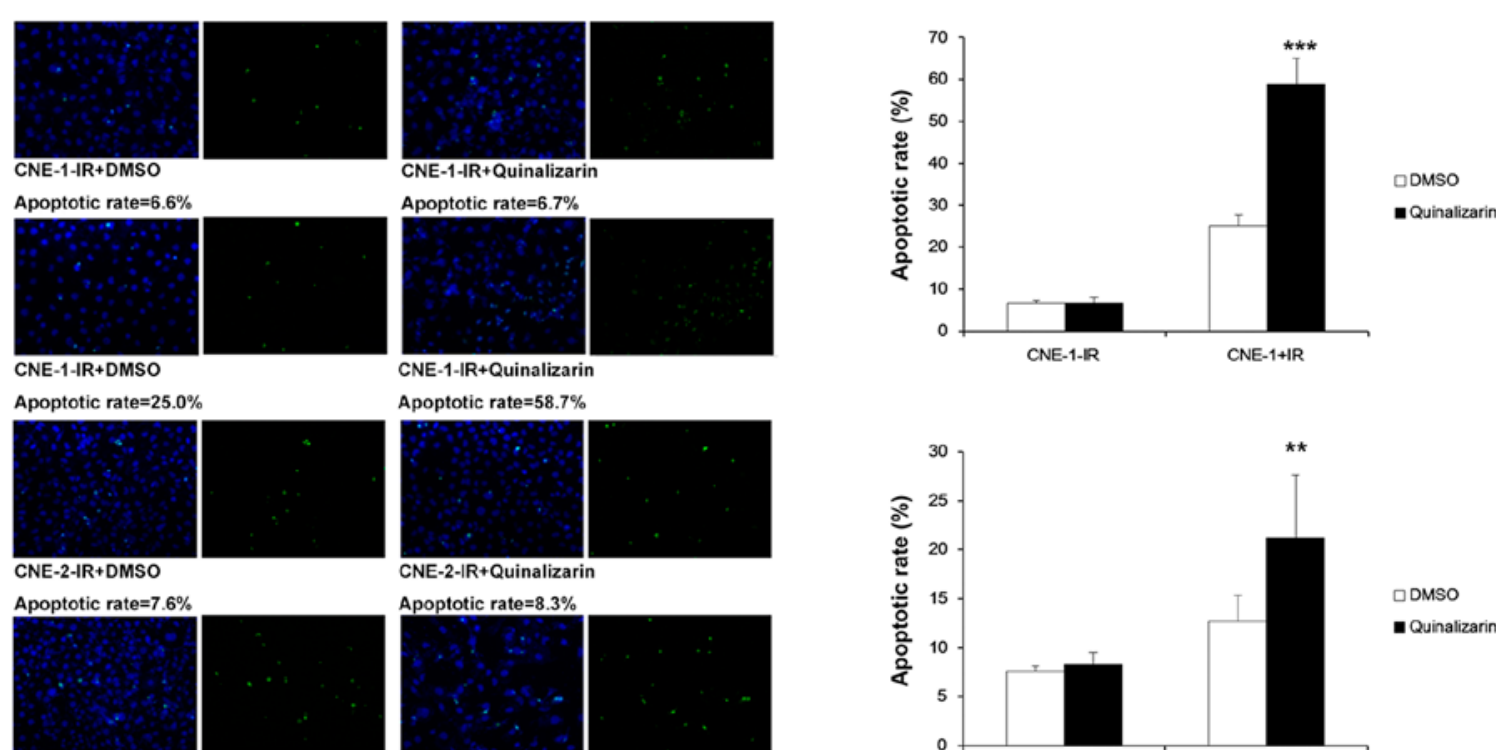

Apoptotic rate $=58.7 \%$

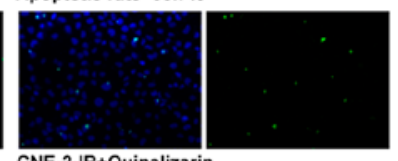

CNE-2-IR+Quinalizarin

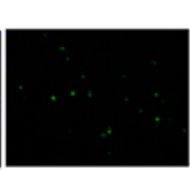

Apoptotic rate $=8.3 \%$

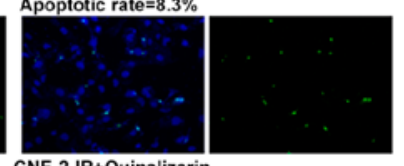

Apoptotic rate $=12.7 \%$

CNE-2-IR+Quinalizarin

Apoptotic rate $=\mathbf{2 1 . 2} \%$

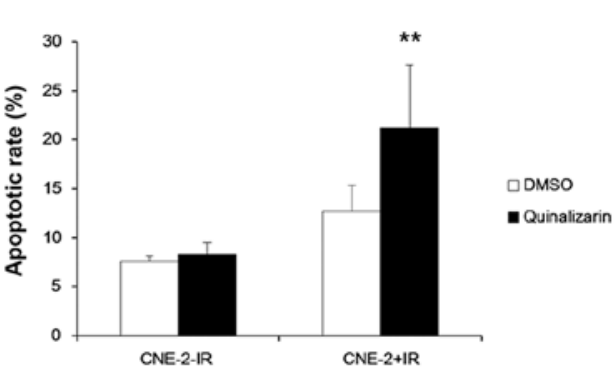

Figure 3. Effects of quinalizarin on cell cycle distribution and cell apoptosis in NPC cells before and after IR. CNE-1 and CNE-2 cells were pretreated with $25 \mu \mathrm{M}$ quinalizarin or $0.05 \%$ DMSO for $24 \mathrm{~h}$, and then irradiated with X-rays (6 Gy). (A) Flow cytometry assays using propidium iodide (PI) staining were used to estimate the cell cycle distribution $24 \mathrm{~h}$ after IR. (B) The apoptosis rates were determined by TUNEL assay $24 \mathrm{~h}$ after IR (magnification, x200). The data are shown as means \pm SD from three independent experiments. ${ }^{*} \mathrm{P}<0.05,{ }^{* *} \mathrm{P}<0.01,{ }^{* * *} \mathrm{P}<0.001$ vs. $0.05 \%$ DMSO group.

of p65 and SHP-1 promoter, both in CNE-1 and CNE-2 cells. However, the effect was not time-dependent (Fig. 6B).
Apart from the binding of p65 and SHP-1 promoter, we also used dual luciferase assay to examine how quinalizarin 

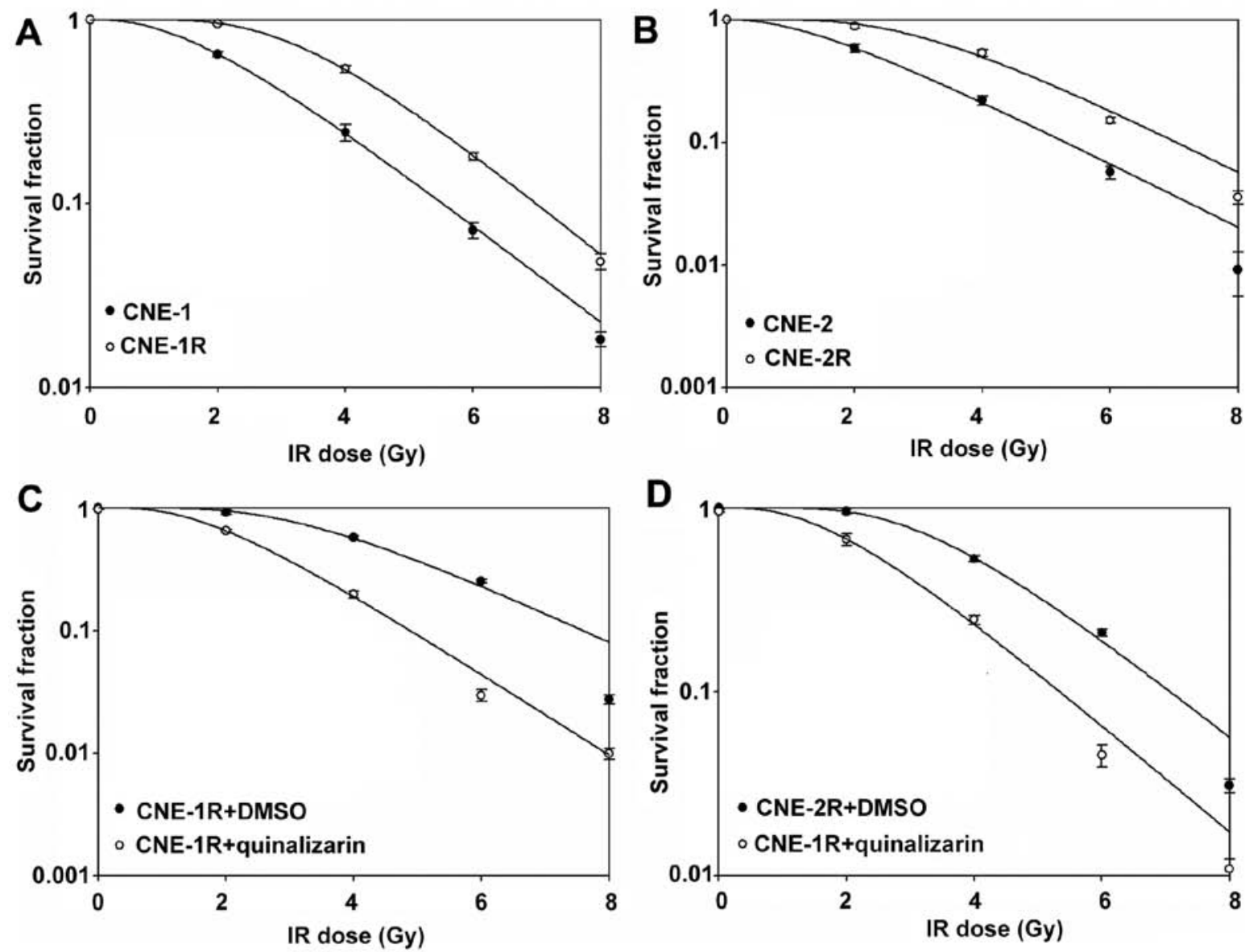

$\mathbf{E}$

$\mathbf{F}$
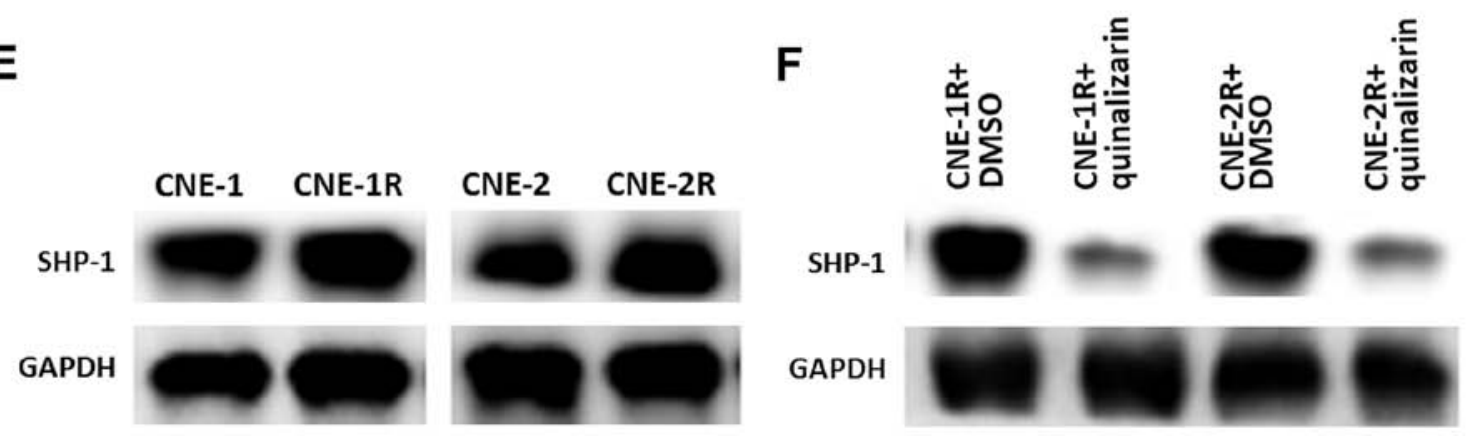

Figure 4. Effect of quinalizarin on SHP-1 expression in radioresistant nasopharyngeal carcinoma (NPC) cells (CNE-1R and CNE-2R). Radiosensitivity of parent CNE-1 cells and radioresistant CNE-1 cells (CNE-1R) (A), and parent CNE-2 cells and radioresistant CNE-2 cells (CNE-2R). (B) Quinalizarin enhanced radiosensitivity of radioresistant CNE-1R (C) and CNE-2R (D) cells. CNE-1R and CNE-2R cells were treated with $25 \mu \mathrm{M}$ quinalizarin for $24 \mathrm{~h}$ and then irradiated at different doses [(0,2, 4, 6 and $8 \mathrm{~Gy}$ ) (radiation absorption rate is $2 \mathrm{~Gy} / \mathrm{min})]$. Clone formation assays were used to examine radiosensitivity of radioresistant NPC cells. (E) SHP-1 expression in parent NPC cells and radioresistant NPC cells. (F) CNE-1R and CNE-2R cells were treated with $0.05 \%$ DMSO or $25 \mu \mathrm{M}$ quinalizarin for $24 \mathrm{~h}$, and then SHP-1 expression was determined by western blot analysis. GAPDH was used as an internal control.

affected the activity of the SHP-1 promoter. As indicated in Fig. 6C, quinalizarin treated cells showed a significant decrease in SHP-1 promoter activity by 36 and $34 \%$ for CNE-1 and CNE-2, respectively.

Quinalizarin suppresses the activity of SHP-1 in NPC cells. Besides regulating the expression of SHP-1, we were also interested in the influence of quinalizarin on the phosphatase activity of SHP-1. We incubated the protein extract with anti-SHP-1 antibodies and use immunoprecipitation to gain purified SHP-1 protein. Then a RediPlate 96 EnzChek Tyrosine Phosphatase Assay kit (R-22067) was used to determine SHP-1 activity. As shown in Fig. 6D, basic activity was normalized to 1.0 (treated with quinalizarin or DMSO for $0 \mathrm{~h}$ ). After treatment with quinalizarin for $12 \mathrm{~h}$, the activity of SHP-1 showed approximately a $10 \%$ decrease compared to the DMSO groups. However, prolonging the treatment to $24 \mathrm{~h}$ did not cause further decrease in SHP-1 activity, thus, the inhibition was not time-dependent.

\section{Discussion}

The purpose of this study was to investigate whether using quinalizarin would increase the radiosensitivity of NPC cells. If this was the case then it may have potential as a method 


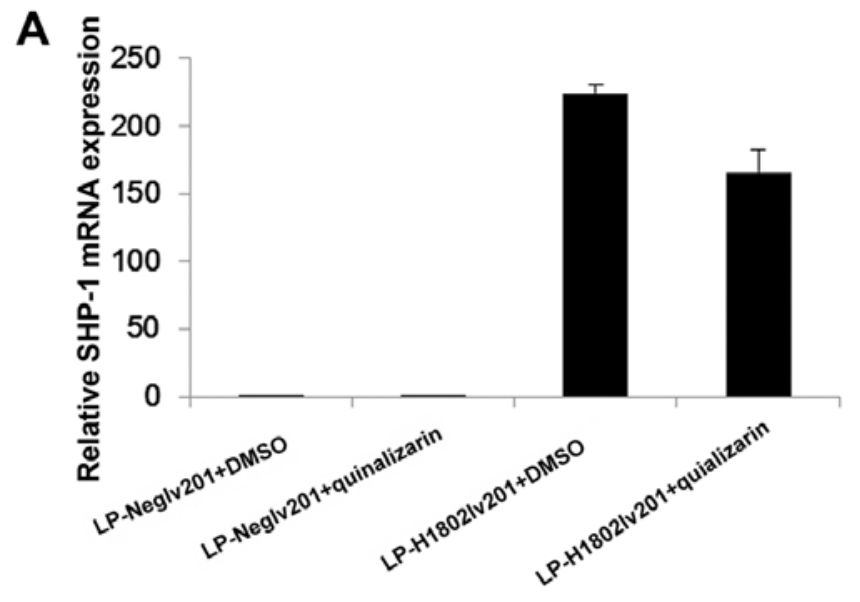

B
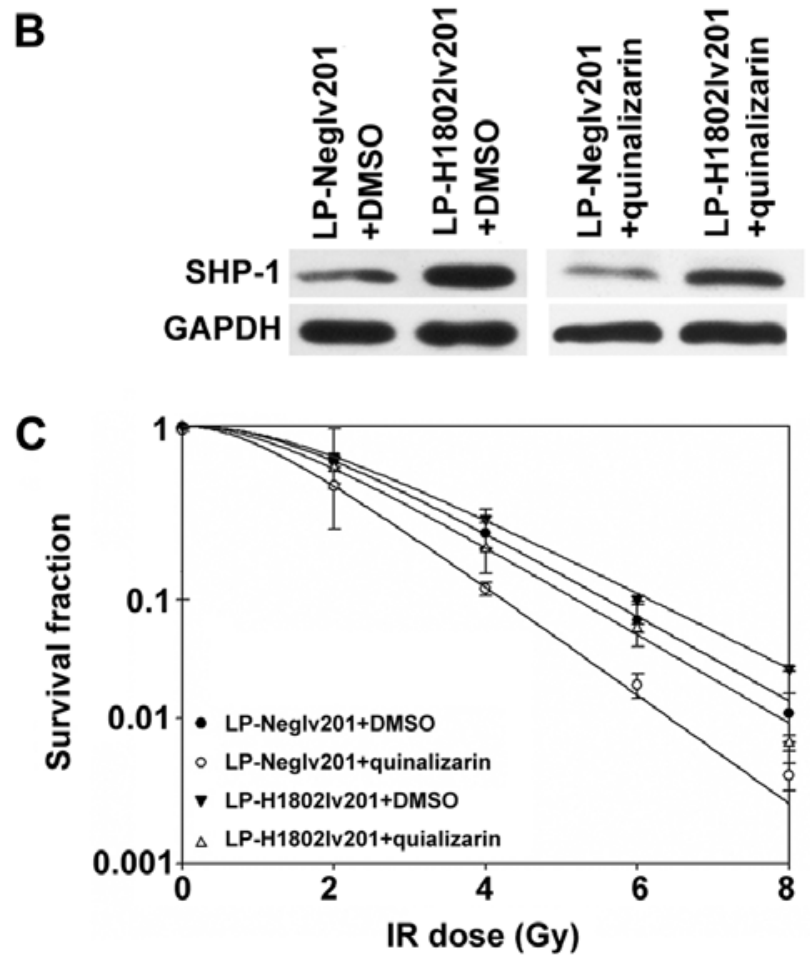

Figure 5. SHP-1 overexpression reverses the radiosensitivity acquired from quinalizarin in CNE-2 cells. CNE-2 cells stably transfected with LP-H1802Lv201 lentivirus to overexpress SHP-1 were treated with $0.05 \%$ DMSO or $25 \mu \mathrm{M}$ quinalizarin for $24 \mathrm{~h}$. LP-NegLv201 was the negative control. (A) SHP-1 mRNA expression was measured by real-time RT-PCR; (B) SHP-1 protein expression was determined by western blot analysis GAPDH was used as an internal control. (C) CNE-2 cells stably transfected with lentivirus were treated with $0.05 \%$ DMSO or $25 \mu \mathrm{M}$ quinalizarin for $24 \mathrm{~h}$, then irradiated at the different doses $[(0,2,4,6$ and $8 \mathrm{~Gy})$ (radiation absorption rate is $2 \mathrm{~Gy} / \mathrm{min})]$. After being further incubated for $\sim 14$ days, clone formation assays were used to examine radiosensitivity of NPC cells. The data are shown as means \pm SD from three independent experiments.

of improving radiation therapy of NPC. The results show that quinalizarin inhibited cell viability, and radiosensitized NPC cells. The mechanism of this induced radiosensitivity involved decreasing the efficiency of DSB repair, increasing the fraction of cells in $\mathrm{G} 2 / \mathrm{M}$ phase and promoting apoptosis. Quinalizarin decreased SHP-1 expression and when SHP-1 was overexpressed the ability of quinalizarin to induce radiosensitivity was partially suppressed suggesting that reducing expression of SHP-1 is involved in the mechanism of quinl- izarin induced radiosensitivity. Firstly, we used MTT assays to determine an appropriate drug concentration. At $25 \mu \mathrm{M}$, the drug itself did not show much cytotoxicity so that we could observe its radiosensitive effect. Then using colony formation assays, we found that quinalizarin enhanced NPC cells radiosensitivity. The enhanced radiosensitivity probably results from delayed DSB repair, increasing cell apoptosis, and larger fraction of cells being in $\mathrm{G} 2 / \mathrm{M}$ phase. $\mathrm{S}$ phase has been shown to provide some degree of radioresistance and G0/G1 are relatively radiosensitive, but G2/M phase shows the most sensitivity to radiation $(30,31)$. Similar results have been seen in other cancers. Kroonen et al concluded that inhibiting CK2 delayed DNA damage repair, but did not radiosensitize malignant glioma cells (32). Liu et al used an RNA interference technique to silence the CK $2 \alpha$ gene in NPC cells and that resulted in higher radiosensitivity (33). Another study also found that CK2 inhibitors enhanced the radiosensitivity of human NSCLC cells by inhibiting stat 3 activation (14).

Our previous investigation found that SHP-1 was highly expressed in NPC tissues in contrast to normal nasopharyngeal mucosa and was associated with local recurrence and metastasis after radiotherapy in NPC patients (27). Further research showed that SHP-1 overexpression increased the radioresistance of NPC cells by enhancing DSB repair, increasing $\mathrm{S}$ phase arrest and decreasing cell apoptosis (34). To assess whether quinalizarin has an influence on SHP-1 expression, we treated NPC cells with quinalizarin and detected the expression of SHP-1. Expression of SHP-1 was obviously inhibited by quinalizarin. The level of SHP-1 was apparently related to the radiosensitivity of the NPC cells $(28,29)$. This encouraged us to try overexpression of SHP-1 and when this was done using lentivirus expression the radiosensitivity induced by quinalizarin was partially suppressed. Thus, it seems likely that quinalizarin radiosensitized NPC cells via a CK2-SHP-1 pathway, at least partially.

It is well known that $\mathrm{NF}-\kappa \mathrm{B}$ is a downstream target of CK2 and is an important transcriptional factor in many cells. The SHP-1 promoter contains a binding site of NF- $\kappa \mathrm{B}$ (35), suggesting that expression of SHP-1 may be regulated by $\mathrm{NF}-\kappa \mathrm{B}$. We treated NPC cells with quinalizarin and detected the phosphorylation level of $\mathrm{p} 65$, and found that quinalizarin inhibited p65 phosphorylation. Furthermore, EMSA and dual luciferase assay suggested that quinalizarin suppressed the activity of SHP-1 promoter by inhibiting p65 binding to SHP-1 promoter. In addition, we also discovered that quinalizarin directly decreased the phosphatase activity of SHP-1. These results further support the theory that CK2p65-SHP-1 pathway may have a role in regulating radiosensitivity and cell cycle distribution in NPC cells (Fig. 7).

In this study, we firstly determined the radiosensitive effect of quinalizarin on NPC cells. This demonstrated that quinalizarin induced radiosensitivity on NPC cells, an important finding that may well prove to have therapeutic use in increasing the effectiveness of radiotherapy for NPC. We also discovered the relationship between CK2 and SHP-1 for the first time in this field. However, the details of the interaction between CK2 and SHP-1 need further study to fully elucidate the pathways involved. In conclusion, quinalizarin radiosensitized NPC cells through inhibiting SHP-1 expression. 
A

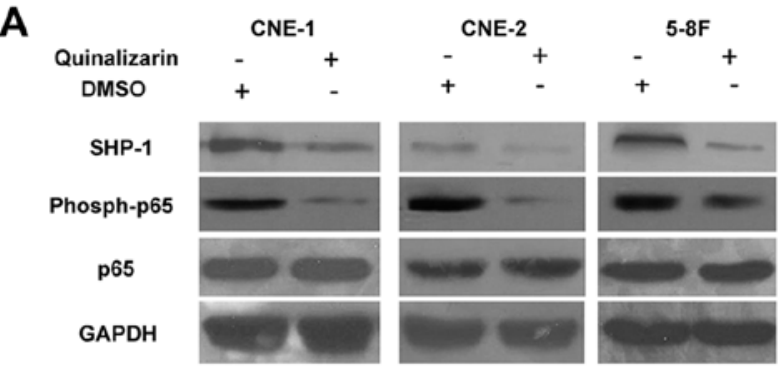

B

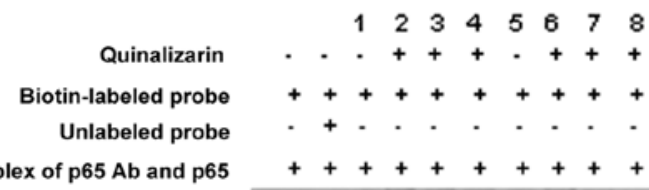

Free probe $\rightarrow$

D

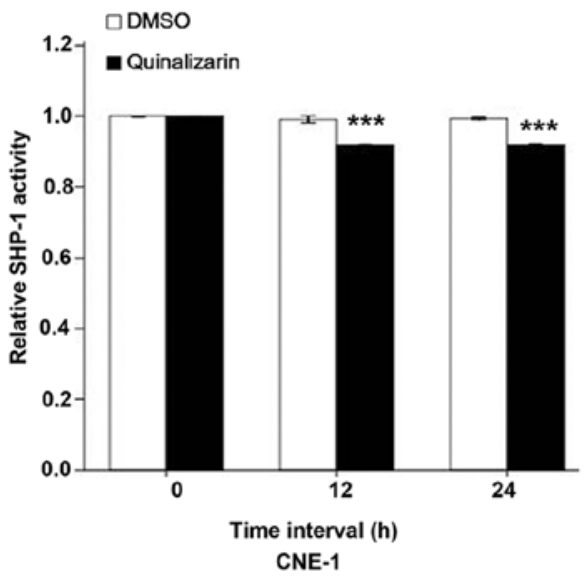

C
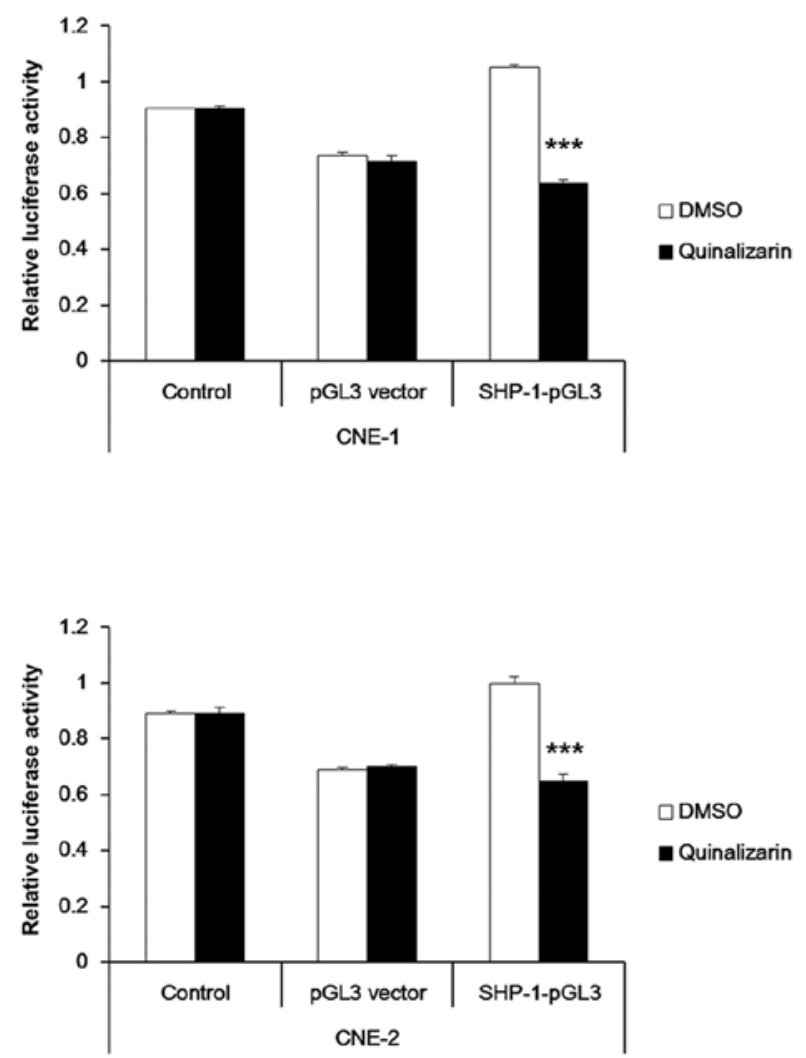

Figure 6. Quinalizarin inhibits binding of p65 and the promoter of SHP-1, and decreases the activities of SHP-1 promoter and SHP-1. (A) NPC cells were treated with $0.5 \%$ DMSO or $25 \mu \mathrm{M}$ quinalizarin for $24 \mathrm{~h}$. SHP-1, p65 and p-p65 protein expression was determined by western blot analysis. (B) Binding of p65 and SHP-1 promoter detected by EMSA. NPC cells CNE-1 and CNE-2 were treated with $25 \mu \mathrm{M}$ quinalizarin for 12,24 and 48 h. Then nuclear extract was incubated with p65 Ab to precipitate p65 and the complex was used in EMSA. Binding of p65 and SHP-1 promoter was inhibited by quinalizarin, but was not time-dependent. 1, CNE-1 not treated with quinalizarin; 2, CNE-1 treated with quinalizarin for $12 \mathrm{~h}$; 3 , CNE-1 treated with quinalizarin for 24 h; 4 , CNE-1 treated with quinalizarin for $48 \mathrm{~h} ; 5, \mathrm{CNE}-2$ not treated with quinalizarin; $6, \mathrm{CNE}-2$ treated with quinalizarin for $12 \mathrm{~h}$; 7 , CNE-2 treated with quinalizarin for $24 \mathrm{~h} ; 8$, CNE-2 treated with quinalizarin for $48 \mathrm{~h}$. (C) Dual luciferase assay of SHP-1 promoter activity. NPC cells CNE-1 and CNE-2 were transfected with SHP-1-pGL3 or pGL3-vector (negative control). Then cells were treated with $0.5 \%$ DMSO or $25 \mu \mathrm{M}$ quinalizarin for $24 \mathrm{~h}$ and dual luciferase assay was used to determine SHP-1 promoter activity. (D) SHP-1 activity of NPC cells. NPC cells were treated with $0.5 \%$ DMSO or $25 \mu \mathrm{M}$ quinalizarin for 12 or 24 h. Total protein was extracted, incubated with anti-SHP-1 antibodies and precipitated by protein A agarose beads to purify SHP-1 protein. Then SHP-1 activity was assayed. The data are shown as means $\pm \mathrm{SD}$ from three independent experiments. ${ }^{*} \mathrm{P}<0.05,{ }^{* *} \mathrm{P}<0.01,{ }^{* * *} \mathrm{P}<0.001$ vs. $0.05 \% \mathrm{DMSO}$ group.

\section{Acknowledgements}

This study was supported by the National Natural Science
Foundation of China in 2012 (no. 81101690), the National Natural Science Foundation of China in 2013 (no. 81301976), and $\mathrm{Wu}$ Jieping Medical Foundation in 2013. 


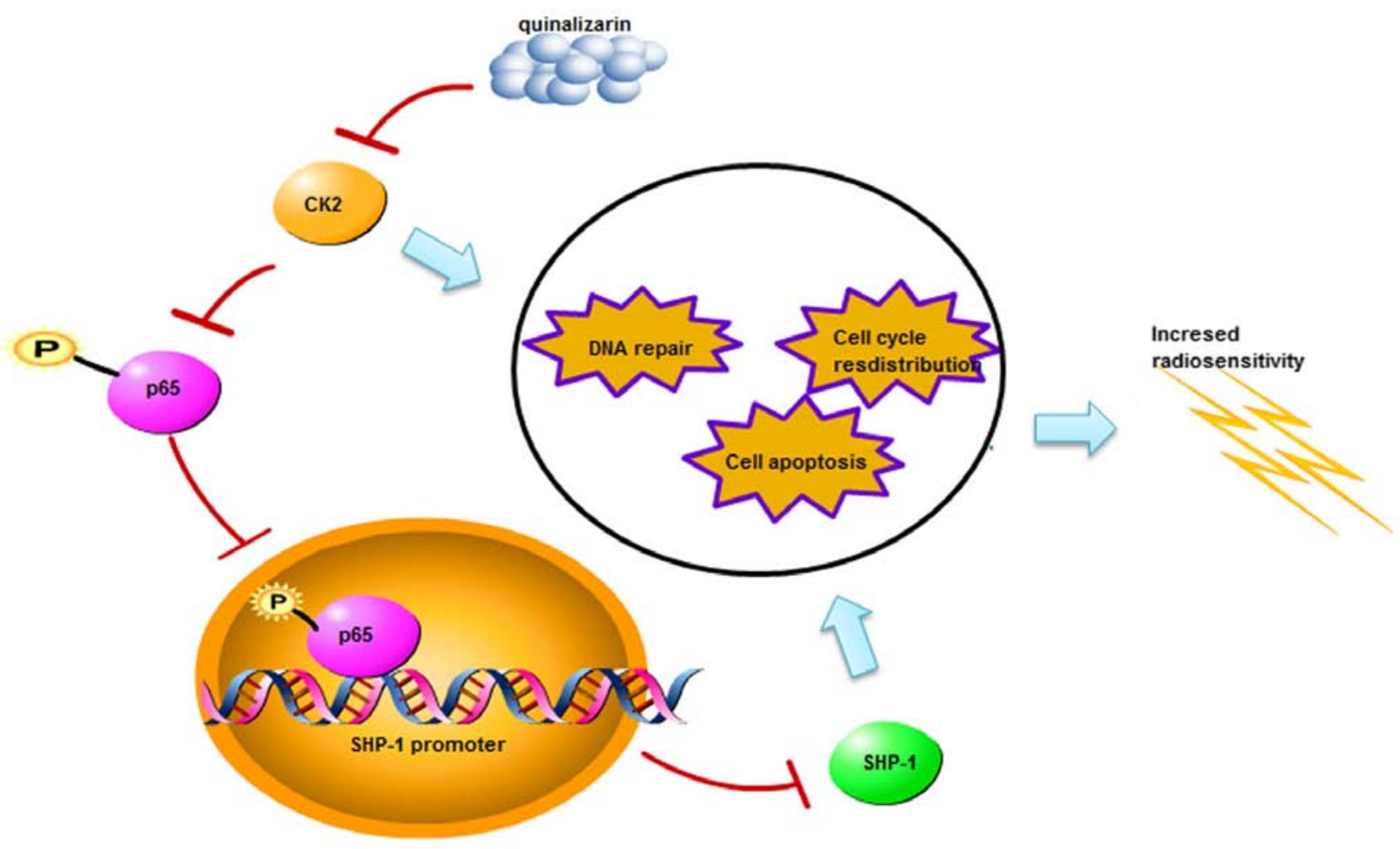

Figure 7. The CK2p65-SHP-1 pathway proposed to have a role in regulating radiosensitivity and cell cycle distribution in NPC cells.

\section{References}

1. Feng XP, Yi H, Li MY, Li XH, Yi B, Zhang PF, Li C, Peng F, Tang CE, Li JL, et al: Identification of biomarkers for predicting nasopharyngeal carcinoma response to radiotherapy by proteomics. Cancer Res 70: 3450-3462, 2010.

2. Iqbal $\mathrm{N}$ and Iqbal N: Imatinib: A breakthrough of targeted therapy in cancer. Chemother Res Pract 2014: 357027, 2014.

3. Sawyers C: Targeted cancer therapy. Nature 432: 294-297, 2004.

4. Giamas G, Man YL, Hirner H, Bischof J, Kramer K, Khan K, Ahmed SS, Stebbing J and Knippschild U: Kinases as targets in the treatment of solid tumors. Cell Signal 22: 984-1002, 2010.

5. Widmer N, Bardin C, Chatelut E, Paci A, Beijnen J, Levêque D, Veal G and Astier A: Review of therapeutic drug monitoring of anticancer drugs part two - targeted therapies. Eur J Cancer 50: 2020-2036, 2014.

6. Trembley JH, Chen Z, Unger G, Slaton J, Kren BT, Van Waes C and Ahmed K: Emergence of protein kinase CK2 as a key target in cancer therapy. Biofactors 36: 187-195, 2010.

7. Gao Y and Wang HY: Casein kinase 2 is activated and essential for Wnt/beta-catenin signaling. J Biol Chem 281: 18394-18400, 2006.

8. Landesman-Bollag E, Song DH, Romieu-Mourez R, Sussman DJ, Cardiff RD, Sonenshein GE and Seldin DC: Protein kinase CK2: Signaling and tumorigenesis in the mammary gland. Mol Cell Biochem 227: 153-165, 2001.

9. Trembley JH, Wang G, Unger G, Slaton J and Ahmed K: Protein kinase CK2 in health and disease: CK2: a key player in cancer biology. Cell Mol Life Sci 66: 1858-1867, 2009.

10. Hagan CR, Regan TM, Dressing GE and Lange CA: ck2-dependent phosphorylation of progesterone receptors (PR) on Ser81 regulates PR-B isoform-specific target gene expression in breast cancer cells. Mol Cell Biol 31: 2439-2452, 2011.

11. Zhu D, Hensel J, Hilgraf R, Abbasian M, Pornillos O, DeyanatYazdi G, Hua XH and Cox S: Inhibition of protein kinase CK2 expression and activity blocks tumor cell growth. Mol Cell Biochem 333: 159-167, 2010.

12. Yefi R, Ponce DP, Niechi I, Silva E, Cabello P, Rodriguez DA, Marcelain K, Armisen R, Quest AF and Tapia JC: Protein kinase CK2 promotes cancer cell viability via up-regulation of cyclooxygenase-2 expression and enhanced prostaglandin E2 production. J Cell Biochem 112: 3167-3175, 2011.
13. Olsen BB, Wang SY, Svenstrup TH, Chen BP and Guerra B: Protein kinase CK2 localizes to sites of DNA double-strand break regulating the cellular response to DNA damage. BMC Mol Biol 13: 7, 2012.

14. Lin YC, Hung MS, Lin CK, Li JM, Lee KD, Li YC, Chen MF, Chen JK and Yang CT: CK2 inhibitors enhance the radiosensitivity of human non-small cell lung cancer cells through inhibition of stat 3 activation. Cancer Biother Radiopharm 26: 381-388, 2011.

15. Pagano MA, Bain J, Kazimierczuk Z, Sarno S, Ruzzene M, Di Maira G, Elliott M, Orzeszko A, Cozza G, Meggio F, et al: The selectivity of inhibitors of protein kinase CK2: An update. Biochem J 415: 353-365, 2008.

16. Cozza G, Mazzorana M, Papinutto E, Bain J, Elliott M, di Maira G, Gianoncelli A, Pagano MA, Sarno S, Ruzzene M, et al: Quinalizarin as a potent, selective and cell-permeable inhibitor of protein kinase CK2. Biochem J 421: 387-395, 2009.

17. Sarno S, de Moliner E, Ruzzene M, Pagano MA, Battistutta R, Bain J, Fabbro D, Schoepfer J, Elliott M, Furet P, et al: Biochemical and three-dimensional-structural study of the specific inhibition of protein kinase CK2 by [5-oxo-5,6-dihydroindolo-(1,2-a)quinazolin-7-yl] acetic acid (IQA). Biochem J 374: 639-646, 2003.

18. Lorenz U: SHP-1 and SHP-2 in T cells: Two phosphatases functioning at many levels. Immunol Rev 228: 342-359, 2009.

19. Banville D, Stocco R and Shen SH: Human protein tyrosine phosphatase 1C (PTPN6) gene structure: Alternate promoter usage and exon skipping generate multiple transcripts. Genomics 27: 165-173, 1995.

20. Evren S, Wan S, Ma XZ, Fahim S, Mody N, Sakac D, Jin T and Branch DR: Characterization of SHP-1 protein tyrosine phosphatase transcripts, protein isoforms and phosphatase activity in epithelial cancer cells. Genomics 102: 491-499, 2013.

21. Nakase K, Cheng J, Zhu Q and Marasco WA: Mechanisms of SHP-1 P2 promoter regulation in hematopoietic cells and its silencing in HTLV-1-transformed T cells. J Leukoc Biol 85: 165-174, 2009.

22. Delibrias CC, Floettmann JE, Rowe $M$ and Fearon DT: Downregulated expression of SHP-1 in Burkitt lymphomas and germinal center B lymphocytes. J Exp Med 186: 1575$1583,1997$. 
23. Oka T, Yoshino T, Hayashi K, Ohara N, Nakanishi T, Yamaai Y, Hiraki A, Sogawa CA, Kondo E, Teramoto N, et al: Reduction of hematopoietic cell-specific tyrosine phosphatase SHP-1 gene expression in natural killer cell lymphoma and various types of lymphomas/leukemias: Combination analysis with cDNA expression array and tissue microarray. Am J Pathol 159: 1495-1505, 2001.

24. Sato K, Horiuchi M, Yo R and Nakarai I: A long survival case of small cell lung cancer synchronized with renal cancer]. Kyobu Geka 44: 251-253, 1991 (In Japanese).

25. Amin HM, Hoshino $K$, Yang $H$, Lin Q, Lai $R$ and Garcia-Manero G: Decreased expression level of SH2 domaincontaining protein tyrosine phosphatase-1 (Shp1) is associated with progression of chronic myeloid leukemia. J Pathol 212: 402-410, 2007

26. López-Ruiz P, Rodriguez-Ubreva J, Cariaga AE, Cortes MA and Colás B: SHP-1 in cell-cycle regulation. Anticancer Agents Med Chem 11: 89-98, 2011.

27. Peng G, Cao R, Xue J, Li P,Zou Z, Huang J and Ding Q: Increased expression of SHP-1 is associated with local recurrence after radiotherapy in patients with nasopharyngeal carcinoma. Radiol Oncol 48: 40-49, 2014.

28. Peng G, Cao RB, Li YH, Zou ZW, Huang J, Ding Q: Alterations of cell cycle control proteins SHP-1/2, p16, CDK4 and cyclin D1 in radioresistant nasopharyngeal carcinoma cells. Mol Med Rep 10:1709-1716, 2014.
29. Cao R, Ding Q, Li P, Xue J, Zou Z, Huang J and Peng G: SHP1mediated cell cycle redistribution inhibits radiosensitivity of non-small cell lung cancer. Radiat Oncol 8: 178, 2013.

30. Hall EJ and Giaccia A (eds): Cell survival curves. In: Radiobiology for the Radiologist. Lippincott Williams \& Wilkins, New York, NY, 2011.

31. Peng G, Cao RB, Li YH, Zou ZW, Huang J and Ding Q: Alterations of cell cycle control proteins SHP-1/2, p16, CDK4 and cyclin D1 in radioresistant nasopharyngeal carcinoma cells. Mol Med Rep 10: 1709-1716, 2014.

32. Kroonen J, Artesi M, Capraro V, Nguyen-Khac MT, Willems M, Chakravarti A, Bours V and Robe PA: Casein kinase 2 inhibition modulates the DNA damage response but fails to radiosensitize malignant glioma cells. Int J Oncol 41: 776-782, 2012.

33. Liu L, Zou JJ, Luo HS and Wu DH: Effect of protein kinase CK2 gene silencing on radiosensitization in human nasopharyngeal carcinoma cells. Nan Fang Yi Ke Da Xue Xue Bao 29: 1551-1553, 2009 (In Chinese).

34. Pan X, Mou J, Liu S, Sun Z, Meng R, Zhou Z, Wu G and Peng G: SHP-1 overexpression increases the radioresistance of NPC cells by enhancing DSB repair, increasing $\mathrm{S}$ phase arrest and decreasing cell apoptosis. Oncol Rep 33: 2999-3005, 2015.

35. Wu C, Sun M, Liu L and Zhou GW: The function of the protein tyrosine phosphatase SHP-1 in cancer. Gene 306: 1-12, 2003. 